\title{
Perbandingan Pemulihan Bising Usus pada Pasien Pascaoperasi Histerektomi per Laparotomi Menggunakan Analgetik Kombinasi Ketamin-Morfin dengan Morfin Intravena
}

\author{
Irvan Setiawan, ${ }^{1}$ Ezra Oktaliansah, ${ }^{2}$ Cindy Elfira Boom ${ }^{2}$ \\ ${ }^{1}$ SMF Anestesiologi dan Terapi Intensif Rumah Sakit Premier Bintaro, \\ ${ }^{2}$ Departemen Anestesiologi dan Terapi Intensif \\ Fakultas Kedokteran Universitas Padjadjaran/Rumah Sakit Dr. Hasan Sadikin Bandung
}

\begin{abstract}
Abstrak
Disfungsi gastrointestinal merupakan penyulit pascaanestesi yang sering terjadi. Tujuan penelitian ini untuk membandingkan pemulihan bising usus antara pemberian analgetika kombinasi ketamin-morfin dibandingkan dengan morfin. Penelitian dilakukan dengan uji klinis acak terkontrol buta ganda terhadap 36 pasien dengan status fisik American Society of Anesthesiologist (ASA) I dan II yang menjalani operasi histerektomi per laparotomi di Rumah Sakit Dr. Hasan Sadikin Bandung pada April-Agustus 2012. Kedua kelompok menerima dosis awal morfin 0,03 mg/kgBB, lalu kelompok K diberikan infus ketamin $4 \mu \mathrm{g} / \mathrm{kgBB} /$ menit, dan kelompok M diberikan morfin infus $10 \mu \mathrm{g} / \mathrm{kgBB} / \mathrm{jam}$. Analisis data memakai uji-t dan Uji Mann Whitney, tingkat kepercayaan $95 \%$ dan bermakna bila $p<0,05$. Hasil penelitian ini menunjukkan waktu pemulihan bising usus pada kelompok K lebih cepat dibandingkan dengan kelompok $\mathrm{M}$ dengan berbeda bermakna $(p<0,05)$. Simpulan, pemulihan bising usus lebih cepat pada pemberian analgetika kombinasi ketamin dan morfin dibandingkan dengan morfin pada pasien pascaoperasi histerektomi per laparotomi.
\end{abstract}

Kata kunci: Ketamin, morfin, pemulihan bising usus

\section{Comparison of Bowel Sound Recovery in Post Operative Hysterectomy per Laparotomy Patient Between Combination of Intravenous Ketamine-Morphine and Morphine}

\begin{abstract}
Gastrointestinal dysfunction is the most common post anaesthesia complication. The aim of this study is to compare the recovery of bowel sounds between combination of ketamine-morphine analgesia to morphine alone. This is a randomized controlled study on 36 patients with American Society of Anesthesiologist (ASA) physical status I and II who underwent hysterectomy per laparotomy at Dr. Hasan Sadikin Bandung during April-August 2012. Both groups received an initial dose of morphine $0.03 \mathrm{mg} / \mathrm{kgBW}$, while K group received intravenous ketamine $4 \mu \mathrm{g} / \mathrm{kgBW} / \mathrm{min}$, and the $\mathrm{M}$ group received morphine $10 \mu \mathrm{g} / \mathrm{kgBW} / \mathrm{hr}$. The results were analyzed using t-test and Mann Whitney test with a confidence level of $95 \%$ and were considered significant if $\mathrm{p}<0.05$. The results of this study showed that the recovery time of bowel sounds in $\mathrm{K}$ group was significantly faster than in the M group $(\mathrm{p}<0.05)$. In conclusion, recovery of bowel sounds is faster in analgesia using combination of ketamine-morphine than morphine in postoperative hysterectomy per laparotomy patients.
\end{abstract}

Key words: Ketamine, morphine, recovery of bowel

Korespondensi: Irvan Setiawan, dr., SpAn, M. Kes, SMF Anestesiologi dan Terapi Intensif Rumah Sakit Premier Bintaro Jl. MH. Thamrin No. 1, CBD Sektor 7 Bintaro Jaya, Tanggerang 15224, Telp/Faks 021-7455500/27625500, Mobile 085221938303,Email irvanstwn@yahoo.com-stwn.irvan@gmail.com" 


\section{Pendahuluan}

Teknik anestesia dan juga analgesia tidak hanya bertujuan memberikan kondisi yang kondusif untuk dilakukan operasi, tetapi juga mencegah komplikasi dan menurunkan morbiditas serta mortalitas masa perioperatif. ${ }^{1}$ Beberapa upaya telah dilakukan untuk memperbaiki keluaran perioperatif dan juga mengurangi komplikasi, seperti penilaian pada saat praoperasi beserta optimalisasi, pencegahan stres pembedahan dan disfungsi organ pascaoperasi, pencegahan dan penanganan nyeri pascabedah, tatalaksana cairan dan nutrisi, penanganan mual muntah, serta pemulihan pascaoperasi. ${ }^{2}$

Disfungsi pada gastrointestinal merupakan penyulit pascaoperasi yang sering kali terjadi. Sekitar $\pm 18 \%$ pasien yang dilakukan operasi histerektomi mengalami ileus pascaoperasi. ${ }^{3}$ Sejak lebih dari 100 tahun lalu, penilaian bising usus merupakan suatu teknik pemeriksaan klinis sederhana, murah dan noninvasif untuk penilaian daerah abdomen, khususnya untuk mendeteksi kasus ileus, sehingga pemeriksaan tersebut dapat dipergunakan untuk penilaian ileus pascaoperasi. ${ }^{4}$

Morfinsebagai prototipe opioid merupakan pilihan utama dalam penatalaksanaan nyeri, terutama nyeri pascaoperasi derajat sedang hingga berat. ${ }^{5,6}$ Opioid bertindak sebagai agonis terhadap reseptor opioid stereospesifik yang terjadi pada pra serta pascasinaps di susunan saraf pusat (SSP) dan jaringan perifer. Morfin dipergunakan sebagai analgetika pascaoperasi dengan dosis 2-5 mg dengan interval 5-10 menit secara titrasi sehingga mencapai level analgetik yang adekuat. ${ }^{6}$ Pemberian kontinu pada orang dewasa diberikan dengan dosis $0,5-2 \mathrm{mg} /$ jam. $^{7}$

Analgetik golongan opioid yang digunakan dalam talaksana nyeri pascaoperasi memberi kontribusi yang besar terhadap kejadian ileus pascaoperasi melalui aktivitas agonis reseptor opioid $\mu$ di sistem gastrointestinal yang dapat menurunkan motilitas usus. ${ }^{8,9}$

Teknik analgesia multimodal dengan cara mempergunakan jenis analgetik hemat opioid telah lama diperkenalkan untuk memperbaiki analgesia dengan cara mengombinasikan obat- obat analgetik dari golongan lain yang dapat memberi efek aditif atau sinergistik, misalnya ketamin. Kombinasi tersebut dapat digunakan untuk menurunkan dosis masing-masing obat sehingga mengurangi efek samping obat yang dipergunakan. Penggunaan analgetika hemat opioid dapat menurunkan ileus pascaoperasi. Penurunan kejadian efek samping ini dapat mengurangi masa perawatan dan memperbaiki pemulihan. ${ }^{10,11}$

Ketamin merupakan antagonis reseptor $N$-methyl-D-aspartate (NMDA) nonkompetitif yang memiliki efek analgetika pada dosis yang rendah (subanestetik). Penggunaan kombinasi ketamin dengan opioid dapat menghasilkan efek hemat opioid dan akan memberikan efek analgetik yang superior dibandingkan dengan memberikan salah satu jenis obat saja. ${ }^{7}$ Telah banyak penelitian dilakukan untuk meneliti efek analgetik ketamin. Beberapa metaanalisis dan juga systematic review telah menyatakan bahwa ketamin infus dosis rendah kontinu merupakan sediaan yang paling efektif untuk tatalaksana nyeri akut pascaoperasi. Ketamin juga menurunkan kebutuhan opioid hingga $50 \%{ }^{7,12-16}$ Dosis yang digunakan adalah $0,15-$ $1,0 \mathrm{mg} / \mathrm{kgBB}$ dengan cara bolus intravena pra dan atau pascaoperasi, serta dapat ditambah dengan infus intraoperatif hingga sebesar 10 $\mu \mathrm{g} / \mathrm{kgBB} /$ menit. $^{17}$

Sebuah penelitian memberikan suatu hasil yang kontradiktif dengan beberapa penelitian yang dilakukan sebelumnya. Sebuah penelitian acak terkontrol tersamar ganda melibatkan 41 orang subjek, meneliti pemberian antara ketamin dosis rendah dan morfin melalui infus terhadap pemulihan fungsi usus pascaoperasi reseksi usus. Pada penelitian ini menggunakan infus ketamin kontinu dengan dosis rendah (2,5 $\mu \mathrm{g} / \mathrm{kgBB} / \mathrm{menit})$. Penggunaan kombinasi morfin-ketamin yang dipakai ternyata tidak mengurangi konsumsi morfin, sehingga tidak ditemukan percepatan pada pemulihan fungsi usus. ${ }^{18}$

Penelitian ini bertujuan untuk mengetahui efektivitas kombinasi ketamin (sebagai efek hematopioid) dengan morfin dalam pemulihan bising usus pada pasien-pasien yang menjalani operasi histerektomi per laparotomi di Rumah 
Sakit Dr. Hasan Sadikin Bandung.

\section{Subjek dan Metode}

Subjek pada penelitian iniadalah pasien-pasien yang dilakukan tindakan pembedahan elektif maupun emergensi, yang memenuhi kriteria penelitian dan juga telah diberikan penjelasan mengenai penelitian serta kesediaan ikut serta dalam penelitian (informed consent). Kriteria inklusi adalah usia 18-60 tahun, pembedahan histerektomi per laparotomi dalam anestesia umum, dan juga status fisik American Society of Anesthesiologist (ASA) I-II. Kriteria eksklusi, yaitu pasien mempunyai alergi terhadap obatobatan yang dipergunakan dalam penelitian, pembedahan laparotomi ulangan, penggunaan nalokson atau opioid antagonis yang lain, serta penambahan analgetika pascaoperasi selain morfin dan juga ketamin. Kriteria pengeluaran adalah mual muntah berat saat pascaoperasi, durasi operasi lebih dari 3 jam, serta ileus yang masih berlangsung lebih dari 3 hari. Penelitian dilakukan di Rumah Sakit Dr. Hasan Sadikin Bandung pada April-Agustus 2012.

Jenis penelitian ini adalah eksperimental dengan melakukan uji klinis rancangan acak lengkap yang terkontrol serta tersamar ganda (double blind randomized controlled trial). Cara pemilihan sampel penelitian dilakukan dengan consecutive sampling dengan alokasi subjek ke dalam salah satu kelompok dilakukan secara randomisasi blok.

Analisis data penelitian dilakukan memakai beberapa uji statistika. Untuk membandingkan perbedaan dua rata-rata menggunakan uji-t jika data berdistribusi normal atau Uji Mann Whitney jika data tidak berdistribusi normal. Uji normalitas data menggunakan Uji Shapiro Wilk, dan kemaknaan ditentukan berdasarkan nilai $\mathrm{p}<0,05$. Data disajikan dalam rata-rata (mean) dan dianalisis menggunakan program statistical product and servise solutions (SPSS) 11,0 for windows.

Setelah mendapat persetujuan penelitian dari Komite Etik Penelitian Kesehatan Fakultas Kedokteran Universitas Padjadjaran/Rumah Sakit Dr. Hasan Sadikin Bandung dan juga telah didapatkan informed consent dilakukan alokasi sampel ke dalam salah satu kelompok secara randomisasi blok. Sampel dibagi menjadi dua kelompok.

Kelompok K (Ketamin) mendapat ketamin melalui infus kontinu dengan dosis $4 \mu \mathrm{g} / \mathrm{kgBB} /$ menit, atau $240 \mu \mathrm{g} / \mathrm{kgBB} / \mathrm{jam}$, yang diberikan dengan cara melarutkan ketamin $240 \mathrm{mg}$ di dalam larutan $\mathrm{NaCl} 0,9 \%$ hingga $50 \mathrm{~mL}$ dengan menggunakan syringe pump dengan kecepatan $0,05 \mathrm{~mL} / \mathrm{kgBB} / \mathrm{jam}$. Kelompok M (Morfin) mendapat morfin infus kontinu dengan dosis $10 \mu \mathrm{g} / \mathrm{kgBB} / \mathrm{jam}$ yang diberikan dengan cara melarutkan morfin $10 \mathrm{mg}$ di dalam $\mathrm{NaCl} 0,9 \%$ hingga $50 \mathrm{~mL}$ dengan mempergunakan syringe pump dengan kecepatan $0,05 \mathrm{~mL} / \mathrm{kgBB} / \mathrm{jam}$.

Setelah pasien tiba di ruang operasi, data hemodinamik basal sebelum induksi dicatat, yang meliputi kesadaran, tekanan darah, laju nadi, laju napas, dan juga saturasi oksigen. Pasien dipasang kateter intravena, kemudian diberikan deksametason $10 \mathrm{mg}$ IV, dan induksi dilakukan dengan mempergunakan propofol 2 $\mathrm{mg} / \mathrm{kgBB}$, fentanil $2 \mu \mathrm{g} / \mathrm{kgBB}$, atrakurium 0,5 $\mathrm{mg} / \mathrm{kgBB}$. Intubasi dilakukan setelah 3 menit.

Pemeliharaan anestesia dilakukan dengan volatil isofluran 1-1,5 MAC, gas $\mathrm{N}_{2} \mathrm{O}: \mathrm{O}_{2}$ dengan perbandingan 50\%:50\%. Fentanil $1 \mu \mathrm{g} / \mathrm{kgBB}$ bolus dapat diberikan bila tekanan darah dan laju nadi meningkat. Atrakurium 0,1 mg/kgBB bolus dapat diberikan untuk mempertahankan relaksasi serta ventilasi terkontrol. Rumatan cairan diberikan kristaloid 1,5 mL/kgBB/jam hingga operasi berakhir. Saat operasi berakhir diberikan ondansetron $4 \mathrm{mg}$ melalui intravena. Neostigmin sebagai reversed pelumpuh otot dapat diberikan dengan dosis maksimal $1 \mathrm{mg}$ intravena bila diperlukan.

Saat berada di ruang pemulihan, pasien diberi analgetik morfin $0,03 \mathrm{mg} / \mathrm{kgBB}$ sebagai dosis awal, selanjutnya diberikan secara infus kontinu menggunakan syringe pump dengan laju 0,05 mL/kgBB/jam. Pemantauan tekanan darah, laju nadi, saturasi oksigen, serta skala nyeri memakai visual analogue scale (VAS) yang dilakukan tiap 30 menit. Bila VAS lebih dari nilai 4 , diberikan morfin bolus intravena sebagai rescue analgesia dengan dosis 0,03 $\mathrm{mg} / \mathrm{kgBB}$, dan dapat diulang dengan interval waktu 10 menit untuk mencapai VAS kurang 
Tabel 1 Karakteristik Subjek Penelitian Kedua Kelompok Perlakuan Kelompok

\begin{tabular}{|c|c|c|}
\hline Karakteristik & $K(n=18)$ & $M(n=18)$ \\
\hline $\begin{array}{l}\text { Usia (tahun) } \\
\text { Rata-rata (SD) } \\
\text { Rentang }\end{array}$ & $\begin{array}{c}44,17(8,91) \\
30-60\end{array}$ & $\begin{array}{c}46,06(5,99) \\
34-54\end{array}$ \\
\hline $\begin{array}{l}\text { Berat badan }(\mathrm{kg}) \\
\text { Rata-rata }(\mathrm{SD}) \\
\text { Rentang }\end{array}$ & $\begin{array}{c}56,39(5,21) \\
50-5\end{array}$ & $\begin{array}{c}56,56(5,65) \\
47-67\end{array}$ \\
\hline $\begin{array}{l}\text { Tinggi badan }(\mathrm{cm}) \\
\text { Rata-rata }(\mathrm{SD}) \\
\text { Rentang }\end{array}$ & $\begin{array}{c}158,56(5,52) \\
145-165\end{array}$ & $\begin{array}{c}157,61(5,04) \\
150-167\end{array}$ \\
\hline $\begin{array}{l}\text { Tekanan darah sistol (mmHg) } \\
\text { Rata-rata (SD) } \\
\text { Rentang }\end{array}$ & $\begin{array}{c}126,44(8,99) \\
114-145\end{array}$ & $\begin{array}{c}126,39(9,36) \\
115-158\end{array}$ \\
\hline $\begin{array}{l}\text { Tekanan darah diastol (mmHg) } \\
\text { Rata-rata (SD) } \\
\text { Rentang }\end{array}$ & $\begin{array}{c}73,39(4,42) \\
65-79\end{array}$ & $\begin{array}{c}72,56(8,00) \\
62-91\end{array}$ \\
\hline $\begin{array}{l}\text { Laju nadi }(\mathrm{x} / \mathrm{mnt}) \\
\text { Rata-rata }(\mathrm{SD}) \\
\text { Rentang }\end{array}$ & $\begin{array}{c}79,28(9,45) \\
63-94\end{array}$ & $\begin{array}{c}74,33(8,78) \\
60-89\end{array}$ \\
\hline $\begin{array}{l}\text { Lama operasi } \\
\text { Rata-rata (SD) } \\
\text { Median } \\
\text { Rentang }\end{array}$ & $\begin{array}{c}137,22(35,74) \\
135,0 \\
50-180\end{array}$ & $\begin{array}{c}133,06(22,95) \\
125,0 \\
90-180\end{array}$ \\
\hline
\end{tabular}

dari 4.

Apabila terjadi mual atau muntah diberikan propofol $20 \mathrm{mg}$ intravena yang dapat diulang apabila masih terjadi mual-muntah hingga 6 jam pascaoperasi, dan apabila terjadi keluhan halusinasi maka diberikan midazolam dengan dosis $2 \mathrm{mg}$ melalui intravena. Penilaian bising usus dilakukan dan juga dicatat tiap 30 menit. Hasil yang positif didapatkan apabila terdapat bising usus lebih dari 2 (dua) kali dalam waktu 30 detik. Pencatatan dilakukan juga terhadap obat-obatan yang telah dipergunakan, seperti larutan analgetik di dalam spuit $50 \mathrm{~mL}$, morfin bolus sebagai obat rescue analgesia, propofol sebagai terapi antimuntah, midazolam untuk halusinasi, beserta waktu pemberian.

\section{Hasil}

Penelitian dilakukan terhadap 36 orang pasien dengan status fisik ASA I dan II yang menjalani operasi histerektomi per laparotomi di Rumah

Tabel 2 Penggunaan Morfin Bolus dan Total Penggunaan Morfin antara Pemberian Kombinasi Ketamin dan Morfin (K) Dibandingkan dengan Morfin Intravena (M) Pascaoperasi Kelompok

\begin{tabular}{lccc}
\hline \multicolumn{1}{c}{ Karakteristik } & K (n=18) & M (n=18) & $\begin{array}{c}\text { Kemaknaan } \\
\text { Nilai } \mathbf{p}\end{array}$ \\
\hline Morfin bolus (mg) & & & 0,134 \\
Rata-rata (SD) & $4,13(2,03)$ & $3,16(1,93)$ & \\
Median & 4,15 & 2,45 & \\
Rentang & $1,5-8,0$ & $1,4-8,0$ & \\
Morfin intravena (mg) & & & 0,001 \\
$\quad$ Rata-rata (SD) & $4,13(2,03)$ & $7,061(2,58)$ & \\
Median & 4,15 & 6,31 & \\
Rentang & $1,5-8,0$ & $3,99-13,36$ & \\
\hline
\end{tabular}


Tabel 3 Perbandingan Waktu Pemulihan Bising Usus antara Pemberian Kombinasi Ketamin dan Morfin (K) Dibandingkan dengan Morfin Intravena (M) Pascaoperasi

\begin{tabular}{|c|c|c|c|}
\hline \multirow{2}{*}{$\begin{array}{c}\text { Waktu } \\
\text { Pemulihan Bising } \\
\text { Usus (Menit) }\end{array}$} & \multicolumn{2}{|c|}{ Kelompok } & \multirow{2}{*}{$\begin{array}{c}\text { Kemaknaar } \\
\text { Nilai p }\end{array}$} \\
\hline & $K(n=18)$ & $M(n=18)$ & \\
\hline $\begin{array}{l}\text { Rata-rata (SD) } \\
\text { Median } \\
\text { Rentang }\end{array}$ & $\begin{array}{c}360,0(60,0) \\
330,0 \\
270-510\end{array}$ & $\begin{array}{c}405,0(55,6) \\
405,0 \\
300-480\end{array}$ & 0,026 \\
\hline
\end{tabular}

Sakit Dr. Hasan Sadikin Bandung yang telah memenuhi kriteria inklusi dan tidak termasuk kriteria eksklusi. Setiap kelompok terdiri atas 18 subjek penelitian.

Hasil uji statistik menggunakan uji-t pada derajat kepercayaan 95\%, menggambarkan bahwa karakteristik umum subjek penelitian berdasarkan usia, berat badan, tinggi badan, tekanan darah sistol dan juga diastol, laju nadi, serta lama operasi di antara kedua kelompok tidak terdapat perbedaan bermakna $(p>0,05$; Tabel 1).

Pemberian morfin bolus pada kelompok M lebih sedikit apabila dibandingkan dengan kelompok K (3,16 vs 4,13 mg). Berdasarkan hasil Uji Mann Whitney dengan menggunakan derajatkepercayaan 95\%, menunjukkan bahwa tidak didapatkan perbedaan bermakna dalam pemberian morfin bolus tersebut. Sementara itu, total morfin intravena yang diberikan pada kelompok M lebih besar dibandingkan dengan kelompok K (7,06 vs 4,13 mg), berdasarkan uji statistika dengan menggunakan independent t-test pada derajat kepercayaan sebesar 95\% terdapat perbedaan yang bermakna pada total pemberian morfin intravena (Tabel 2).

Waktu yang dibutuhkan untuk pemulihan suara bising usus pada kelompok M ialah 405 menit, sedangkan waktu kelompok $\mathrm{K}$ adalah 360 menit. Hasil uji statistika mempergunakan independent $t$-test dengan derajat kepercayaan $95 \%$, menunjukkan terdapat perbedaan yang bermakna dalam waktu pemulihan bising usus pemberian kombinasi ketamin dan morfin (K) dibandingkan dengan morfin intravena (M) (Tabel 3).

Pada hasil penelitian ini didapatkan pula kejadian efek samping pascaoperasi berupa mual pada kelompok K sebanyak 1 pasien, sedangkan pada kelompok M terjadi pada 3 orang. Selain kejadian efek samping tersebut, pada penelitian ini ternyata tidak didapatkan efek samping pemberian ketamin dan morfin, baik dalam waktu segera setelah perlakuan maupun selama di dalam pengamatan hingga didapatkan hasil bising usus positif.

\section{Pembahasan}

Pemberian analgetik multimodal pascaoperasi mulai banyak diterapkan untuk menekan efek opioid yang merugikan, salah satu di antaranya adalah waktu pemulihan ileus pascaoperasi yang lebih lama. Secara praktis, dibutuhkan suatu formulasi dosis ketamin yang memadai untuk dapat menurunkan kebutuhan morfin, sehingga pemulihan usus pascaoperasi, dalam hal ini pemulihan bising usus, dapat dicapai dalam waktu yang lebih cepat.

Penelitian ini mempergunakan subjek yang hampir sama, yaitu pada wanita yang menjalani operasi histerektomi. Dari data karakteristik umum subjek penelitian (Tabel 1) di antara kedua kelompok perlakuan, yaitu kelompok kombinasi ketamin dan morfin dibandingkan dengan kelompok morfin intravena, ternyata secara statistik tidak menunjukkan perbedaan bermakna dalam hal usia, tinggi badan, berat badan, tekanan darah sistol dan diastol, laju nadi, dan juga lama operasi di antara kedua kelompok perlakuan ( $p>0,05)$, sehingga kedua kelompok perlakuan dianggap homogen serta layak untuk dibandingkan.

Faktor-faktor yang harus dipertimbangkan karena akan memengaruhi pemulihan fungsi gastrointestinal, antara lain jenis operasi, lama operasi, dan manipulasi usus yang dilakukan selama operasi. ${ }^{19}$ Penelitian ini dilakukan pada 
satu jenis operasi, yaitu histerektomi dengan asumsi manipulasi usus yang sama dan lama operasi yang sama, dengan demikian kedua kelompok tersebut homogen dan layak untuk dibandingkan.

Seperti telah dijelaskan sebelumnya, bahwa pada kelompok K tidak mendapatkan morfin infus kontinu, namun pemberian morfin pada kelompok K hanya pada saat pemberian bolus intravena. Meskipun data penggunaan morfin bolus rata-rata pada kelompok K (kombinasi ketamin dengan morfin) lebih besar daripada kelompok M (morfin intravena) $(4,133 \pm 2,031$ mg vs. $3,161 \pm 1,926 \mathrm{mg}$ ), tetapi secara statistik mempergunakan Uji Mann-Withney ternyata jumlah morfin bolus tersebut tidaklah berbeda secara bermakna $(p=0,134)$. Total penggunaan morfin baik bolus maupun kontinu (terutama kelompok M), pada kedua kelompok perlakuan, yaitu pada kelompok kombinasi ketamin dan morfin dibandingkan dengan morfin intravena menunjukkan terdapat perbedaan yang sangat bermakna $(4,133 \pm 2,031 \mathrm{mg}$ vs. 7,061 $\pm 2,576$ mg; $\mathrm{p}=0,001$ ). Kondisi ini menunjukkan bahwa kombinasi ketamin dan morfin menghasilkan konsumsi morfin yang lebih rendah daripada pemakaian morfin saja dengan selisih ratarata $2,928 \mathrm{mg}$.

Kombinasi ketamin dengan morfin sebagai analgesia multimodal ini dimaksudkan untuk menurunkan dosis opioid yang dipergunakan, sesuai prinsip analgetik hemat opioid. Sebuah systematic review menyatakan bahwa ketamin mempunyai efek hemat opioid bila digunakan pada prosedur pembedahan yang mempunyai derajat nyeri sedang hingga berat. Sebaliknya, pada prosedur operasi yang mengakibatkan derajat nyeri yang ringan, ketamin tidak dapat memberikan efek hemat opioid. ${ }^{20}$ Prosedur histerektomi merupakan suatu prosedur yang mengakibatkan derajat nyeri sedang hingga berat, ${ }^{6}$ sehingga pemberian kombinasi ketamin dan morfin pada prosedur histerektomi dapat menurunkan kebutuhan opioid.

Pada kelompok kombinasi ketamin dengan morfin, digunakan regimen ketamin intravena kontinu dosis $4 \mu \mathrm{g} / \mathrm{kgBB} /$ menit, tanpa loading dose, ketamin pada dosis tersebut merupakan dosis paling kecil yang dapat menimbulkan efek analgetika dan juga efek hemat opioid hingga mencapai 50\%., ${ }^{72-16}$ Pemberian opioid mempergunakan dosis minimal ini diharapkan dapat menekan efek samping ketamin pada sistem susunan saraf pusat. Berdasarkan hasil penelitian ini, pemberian regimen ketamin 4 $\mu \mathrm{g} / \mathrm{kgBB} /$ menit dapat menghemat kebutuhan opioid sebanyak $41,46 \%$. Terdapat perbedaan bermakna pada waktu yang diperlukan untuk mendapatkan bising usus positif pascaoperasi antara kelompok K (kombinasi ketamin dan morfin) dan kelompok M (morfin). Hasil ini menunjukkan bahwa kombinasi ketamin dan morfin mempunyai efek pemulihan usus yang lebih cepat dibandingkan dengan kelompok morfin intravena.

Pada penelitian ini menggunakan ketamin dosis $4 \mu \mathrm{g} / \mathrm{kgBB} / \mathrm{menit}$, lebih besar daripada dosis penelitian sebelumnya, tetapi merupakan dosis terkecil yang dapat dipergunakan tanpa loading dose. ${ }^{7}$ Pada penelitian ini memberikan hasil yang kontradiktif dengan hasil penelitian sebelumnya. Studi tersebut dilakukan pada operasi reseksi kolon dengan mempergunakan ketamin intravena kontinu dosis $2,5 \mu \mathrm{g} / \mathrm{kgBB} /$ menit, dan kurang memberikan efek analgetika yang adekuat, sehingga tidak memberikan efek hemat opioid. Sebagai konsekuensi ialah hasil yang tidak bermakna dalam hal mempercepat pemulihan bising usus. ${ }^{8}$

Pada penelitian ini mendapatkan temuan lain berupa kejadian mual pada 1 dari 18 orang kelompok K dan 3 dari 18 orang kelompok M, dan tidak terdapat kejadian muntah. Hasil ini memberikan kesan bahwa kejadian mual pada kelompok K lebih tinggi daripada kelompok M. Meskipun kedua regimen obat, baik morfin maupun ketamin, dilaporkan mempunyai efek samping mual dan muntah, kombinasi ketamin dan juga morfin justru menurunkan kejadian mual dan muntah. ${ }^{14}$ Namun, masih dibutuhkan penelitian tentang efek samping penggunaan obat tersebut dengan mempergunakan jumlah sampel yang lebih besar.

Efek samping ketamin pada sistem saraf pusat seperti halusinasi dan juga mimpi buruk ditemukan pada dosis yang cukup besar, yaitu pada kadar ketamin dalam plasma lebih dari 200 ng/mL. Penelitian ini tidak mengukur 
kadar ketamin di dalam plasma darah, tetapi apabila merujuk pada penelitian sebelumnya, dengan pemberian ketamin $1 \mathrm{mg} / \mathrm{kgBB}$ bolus intravena dan juga dilanjutkan infus kontinu $4 \mu \mathrm{g} / \mathrm{kgBB} /$ menit, konsentrasi dalam plasma didapatkan 179 ng/mL. ${ }^{7}$ Dapat diasumsikan bahwa ketamin infus kontinu yang diberikan mempergunakan dosis $4 \mu \mathrm{g} / \mathrm{kgBB} /$ menit tidak menimbulkan efek samping sistem saraf pusat, seperti yang didapatkan pada penelitian ini.

Keterbatasan pada penelitian ini adalah penilaian pemulihan bising usus merupakan variabel penilaian sederhana dalam pemulihan gastrointestinal secara klinis. ${ }^{18,21}$ Penilaian lain yang dapat digunakan, yaitu penilaian flatus dan pasase feses tidak dilakukan.

\section{Simpulan}

Berdasarkan pengujian hasil penelitian dan juga pembahasan maka dapat dirumuskan simpulan bahwa waktu pemulihan bising usus pascaoperasi kelompok K (kombinasi antara ketamin dan morfin) lebih cepat dibandingkan dengan kelompok M (morfin).

\section{Daftar Pustaka}

1. Bonnet F, Marret E. Influence of anaesthetic and analgesic techniques on outcome after surgery. Br J Anaesth. 2005;95(1):52-8.

2. Kehlet H, Dahl JB. Anaesthesia, surgery, and challanges in postoperative recovery. Lancet. 2003;362:1921-8.

3. Salvador CG, Sikirica M, Evans A, Pizzi L, Goldfarb N. Clinical and economic outcomes of prolonged postoperative ileus in patients undergoing hysterectomy and hemicolectomy. P\&T. 2005;30(10):590-5.

4. Gu Y, Lim HJ, Moser MAJ. How useful are bowel sounds in assessing the abdomen? Dig Surg. 2010;27:422-6.

5. Savoia G, Ambrosio F, Paoletti F, Bertini L, Mattia C, Amantea B, dkk. SIAARTI recommendations for treatment of postoperative pain. Minerva Anesthesiol. 2002;68:735-50.

6. Costantini R, Affaitati G, Fabrizio A,
Giamberardino MA. Controlling pain in the post-operative setting. Int J Clin Pharm Ther. 2011;49(2):116-27.

7. Schmid RL, Sandler AN, Katz J. Use and efficacy of low-dose ketamine in the management of acute postoperative pain: a review of current techniques and outcomes. Pain. 1999;82:111-25.

8. Holte $\mathrm{K}$, Kehlet H. Postoperative ileus: progress towards effective management. Drugs. 2002;62(18):2603-15.

9. Senagore AJ. Improving the management of postoperative ileus: impact on clinical and economic outcomes. Am J Health-Syst Pharm. 2007;64(Suppl 13):S3-7.

10. Pyati S, Gan TJ. Perioperative pain management. CNS Drugs. 2007;21(3)185211.

11. Buvanendran A, Kroin JS. Multimodal analgesia for controlling acute postoperative pain. Curr Opin Anesth. 2009;22:588-93.

12. Subramaniam K, Subramaniam B, Steinbrook RA. Ketamine as adjuvant analgesic to opioids: a quantitative and qualitative systematic review. Anesth Analg. 2004;99:482-95.

13. Elia N, Tramer MR. Ketamine and postoperative pain - a quantitative systemic review of randomised trials. Pain. 2005;113:61-70.

14. Bell RF, Dahl JB, Moore RA, Kalso E. Peri-operative ketamine for acute postoperative pain: a quantitative and qualitative systematic review (Cochrane review). Acta Anaesthesiol Scand. 2005;49:1405-28.

15. Hocking G, Visser EJ, Schug SA, Cousins MJ. Ketamine: does life begin at 40? Pain: Clin Updates. 2007;15(3):1-6.

16. Carstensen M, Moller AM. Adding ketamine to morphine for intravenous patient-controlled analgesia for acute postoperative pain: a qualitative review of randomized trials. $\mathrm{Br} \mathrm{J}$ Anaesth. 2010;104(4):401-6.

17. McCartney CJL, Sinha A, Katz J. A qualitative systematic review of the role of N-methyl$\mathrm{D}$-aspartate receptor antagonists in 
preventive analgesia. Anesth Analg. 2004;98:1385-400.

18. McKay WP, Donais P. Bowel function after bowel surgery: morphine with ketamine or placebo; a randomized controlled trial pilot study. Acta Anaesthesiol Scand. 2007;51:1166-71.

19. Ay AA, Kutun S, Uluncanlar H, Tarcan
0, Demir A, Cetin A. Risk factors for postoperative ileus. J Korean Surg Soc. 2011;81:242-9.

20. Scheinin B, Lindgren L, Scheinin TM. Perioperative nitrous oxide delays bowel function after colonic surgery. Br J Anaesth. 1990;64:154-8. 